\title{
Do duties of students of medicine be cause for stress?
}

\begin{abstract}
Introduction. For young adults, one of the sources of peer interaction problems is the fact that they are burdened with an increasing number of duties and their pace of life increases. Since they are usually burdened with huge amount of study material, medicine students are particularly vulnerable.

Aim. The aim of this work was to determine the relationship between their obligations, stress levels and their peer or family relationships.

Material and methods. The study involved 242 students (148 women and 94 men) of the first year of daily studies, aged 18-30 (median - 20 years). The assessment was performed in March 2016, and the research tool was an anonymous survey. This took into account, inter alia, data on the demands of their studies, and their peer and family affinities.

Results. Using the results, around $71 \%$ of all respondents consider themselves to be over-burdened with the obligations resulting from their choice of study. Among these, women were more likely to self-assess themselves as overburdened (65\%). Moreover, out of all respondents, approx. $27 \%$ of all, considered excessive workload as a major source of stress. This, however, does not significantly affect their peer and family relationships, because approx. $95 \%$ of all respondents consider such these to be be either good or rather good.

Conclusions. Medical students are burdened with responsibilities. This can be a source of stress, but overall, does not affect social and family associations.
\end{abstract}

Keywords: responsibilities, students, teaching load, stress.

DOI: $10.1515 /$ pjph-2016-0025

\section{INTRODUCTION}

For young adults, burdens and responsibilities appearing in everyday life can induce stress and negatively affect their social affinities. Such obligations, both in and out of college, translate into emotional tension, which on the one hand, can mobilize and motivate, while, on the other hand, can bring about a loss of interest in their surroundings [1-3]. Today, poor mental conditioning and behavioral disorders can be seen in diverse cultural groups and in both sexes, as well as in all age levels $[4,5]$.

According to current literature, this is a global phenomenon. Worldwide, various mental disorders and illnesses affect approximately 450 million people. According to various sources, in Europe this figure might be reaching the level of approx. 50 million (11\% of the population) [6]. Indeed, it is predicted that within the next 20 years, the incidence of depressive disorders will come second to cardiovascular diseases regarding the worldwide health burdens [6].

Such forecasts are particularly alarming when taking into account the fact that these figures pertain to the psychosocial health of children and adolescents. With regard to these, it is estimated that in Poland alone, $10-20 \%$ of the total population of all children and adolescents might be afflicted with various mental disorders [7]. In contrast, relatively little is known with respect to those undertaking formal studies at the university level. Students of medical sciences, due to the nature of their studies, might be particularly vulnerable. Among all such individuals, first-year students, who have to deal with a significant change of mode and pace of learning, with a radically different environment and a significant burden of study material that they have to absorb in a relatively short period of time, can have problems adapting to the new requirements and organizing their learning [8]. Hence, they face increased susceptibility to mental disorders.

The studies conducted by Skrzypek et al. show that individuals attending medical studies differ significantly from the students of other faculties in terms of the self-perceived overall quality of life and ability to deal with stress. Medicine students are shown to perceive themselves as having a lower quality of life in terms of mental stress and being less likely to have a successful strategy for coping with problems related to the lives they lead [9]. In general, unfortunately, the scale of the phenomenon is poorly understood in Poland. This is partially because such students are reluctant to seek any professional help. The few studies that have been done indicate that nearly $22 \%$ of all such students have actually sought the help of a psychologist or psychiatrist, while $36 \%$ of all such 
students have declared their willingness to participate in psychological therapy [10]. In other European countries, the need to seek psychological or psychiatric help is recognized without any stigma and it is considered as an aspect of following a healthy lifestyle. For example, in the UK, $40 \%$ of the entire population of medicine students have sought help to relieve or cope with problems associated with anxiety, tension and difficulties in concentration.

Further research suggests, unfortunately, that medical students who have experienced or who are going through episodes of depression and distress achieve lower scores in their line of study $[11,12]$. Recognition of this phenomena is not new, the notion of stress as a psychological state of being was first introduced in 1926, by Hans Seyla, a medical student who became a prominent endocrinologist. Accordingly, stress is "a condition that manifests a kind of a team consisting of all non-specific changes in the biological system. Its components are visible changes caused by it, regardless of the cause" [11]. Reasons for stress can be simple and easily recognizable, e.g. adverse environmental conditions, excessive workload and level of responsibility, excessive noise and poor lighting. More complex and insidiously operating stressors of social nature are: employee or student tasks exceeding both the competence and knowledge possessed by the students, sudden or continuous excessive workload, time constraints and the need for rapid decision-making, as well as adverse workplace relationships [8]. Due to limited research on the degree and type of stress that medicine students are facing, as well as their study load and mental health, the goal of our study was to determine the relationship between the burdens of study and the resulting stress and mental disorders.

\section{MATERIAL AND METHODS}

The study involved 242 students (148 women and 94 men) who were first-year students of medicine, aged 18-30 (median -20 years) (Figure 1 ).

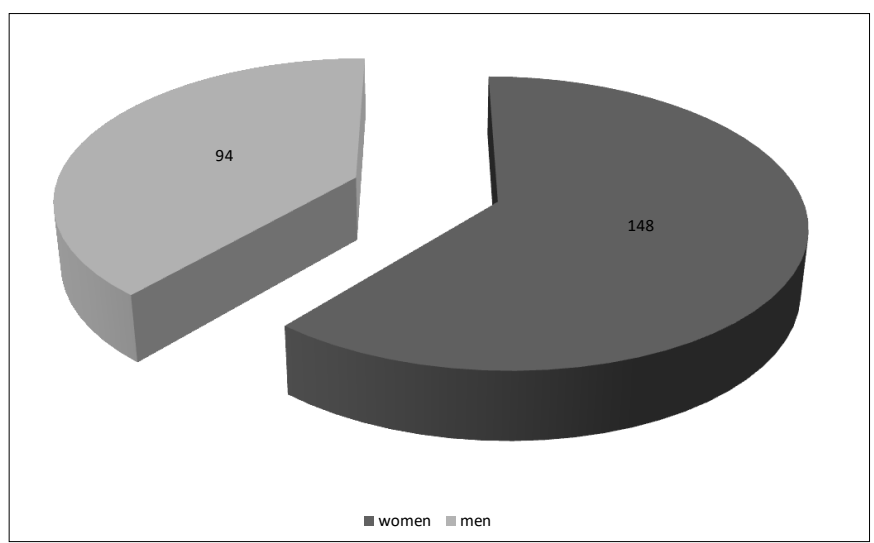

FIGURE 1. The number of people with gender consideration.

The survey was carried out in March 2016. The authors used an anonymous questionnaire looking at, among others, age, sex and place of residence and other information regarding the burdens of their study, their susceptibility to mood disorders, and state of their peer and family associations.

The results were statistically analysed using Pearson's $\mathrm{Chi}^{2}$ test of independence, with significance set at $\mathrm{p}<0.05$, via the program Statistica 11.0. They are summarized in the form of tables.

\section{RESULTS}

Initially, the respondents were asked whether they felt overburdened with their university-related responsibilities. Most of the students $(45.45 \%)$ affirmed this situation, with more women being affected $(50.68 \%$ of all respondents; among men, this figure was approx. $37.23 \%$ ). The remainder mostly self-assessed the situation as 'rather yes' (about $25.62 \%$ of all respondents, including $25.68 \%$ of all women and $25.53 \%$ of all men). In contrast, $8.51 \%$ of all males and $2.70 \%$ of all females (for a total of $4.69 \%$ of all respondents) claimed that they did not feel overburdened, while $21.49 \%$ of all respondents (including $18.24 \%$ of all women and $26.60 \%$ of all men) chose the category of 'Rather no', and $2.48 \%$ (2.70\% of all women and $2.13 \%$ of all men) chose the category Undecided' (Figure 2).

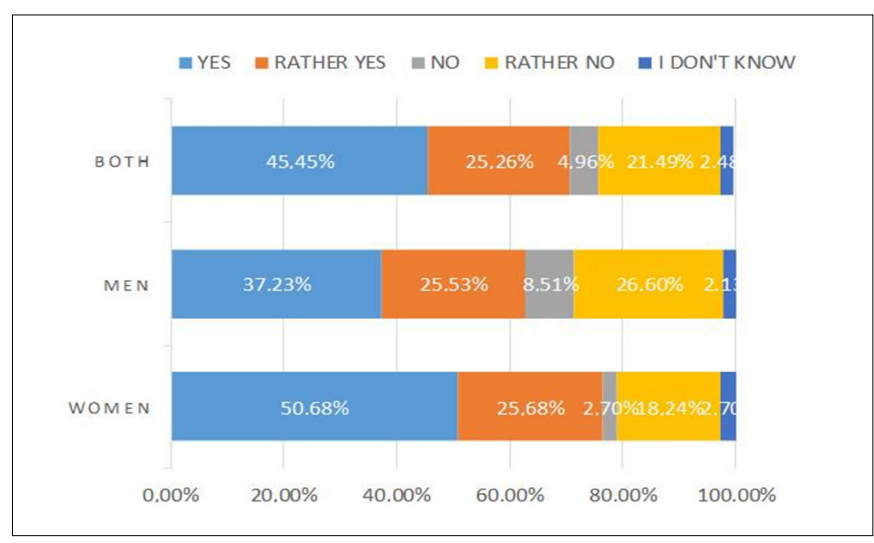

FIGURE 2. Do you feel overburdened with your studies? (Pearson's Chi ${ }^{2}$ : 8.64961, $\mathrm{df}=5, \mathrm{p}=\mathbf{0 . 1 2 3 8 8 3}$ ).

Subsequently, students answered the question as to whether they had enough free time. Some $20.21 \%$ of all males and $5.41 \%$ of all females chose 'Yes', which translated into a total figure of $11.16 \%$ of all respondents. The answer 'Rather - yes' was chosen by $15.96 \%$ of all men and $26.35 \%$ of all women (for a total $22.31 \%$ of all respondents). For those who chose 'No', the figure was $26.59 \%$ of all men and $39.19 \%$ all women (for a total of $34.29 \%$ of all respondents), while for those who chose 'Rather no', the figures were $31.91 \%$ of all men and $26.35 \%$ of all women (for a total of $28.51 \%$ of all respondents). The category of 'I don't know' was chosen by $5.42 \%$ of all males and $2.70 \%$ of all females (for a total of $3.72 \%$ of all respondents) (Figure 3).

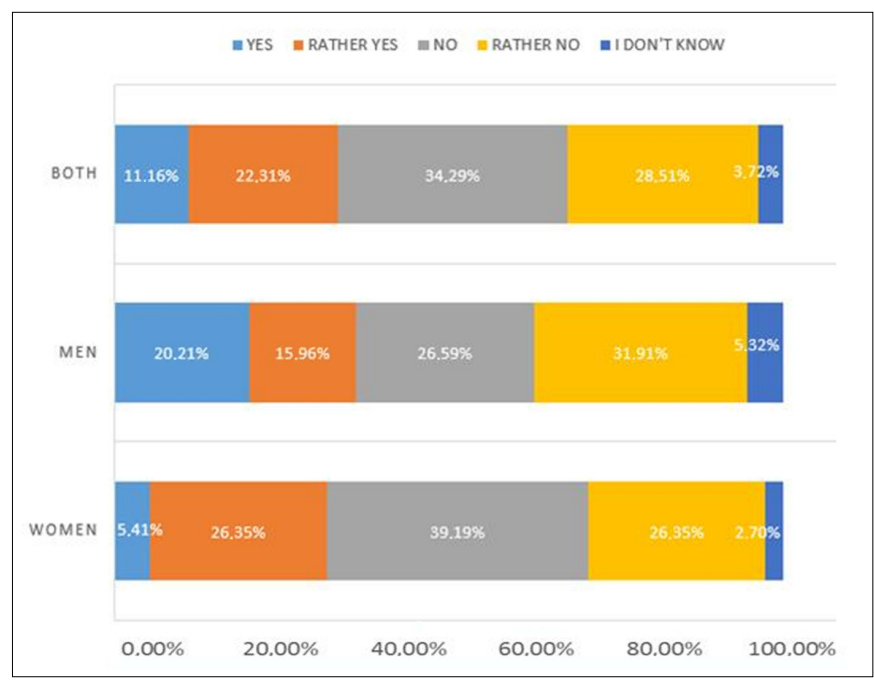

FIGURE 3. Do you have enough leisure time? (Pearson's Chi': 20.5020, df $=5, p=0.001006$ ). 
Another question that the authors asked regarded the amount of stress that particular studies induce. Most of the respondents chose 'Rather yes'. In the study, the figures were: $68.09 \%$ of all males and $63.51 \%$ of all females (for a total of $65.29 \%$ of all respondents). The category 'Yes' was chosen by $15.96 \%$ of all men and $33.78 \%$ of all women (for a total of $26,86 \%$ of all respondents). Some $3.19 \%$ of all males and $1.35 \%$ of all females claimed that their studies did not induce stress (a total of $2.06 \%$ of all respondents), while 'Rather not' was chosen by $12.77 \%$ of all men and $1.35 \%$ of all women (for a total of $5.79 \%$ of all respondents) (Figure 4 ).

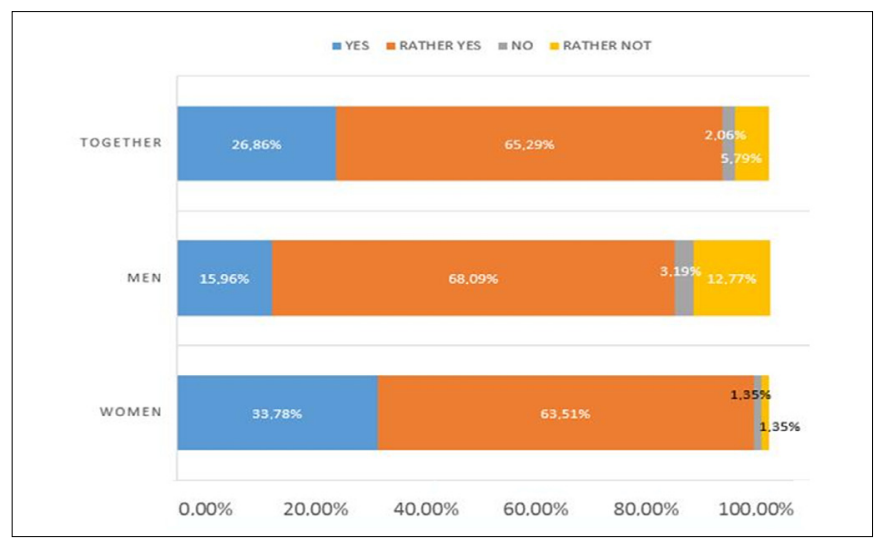

FIGURE 4. Do your studies induce stress?

(Pearson's Chi': 21.7169, df=4, $\mathrm{p}=\mathbf{0 . 0 0 0 2 2 8}$ ).

There is an interesting comparison regarding the degree of study load in the first year effect to that of social activity. Within this category, the vast majority of respondents stated that they have good relations with their peers. Overall, about $95 \%$ of all male and female respondents chose to state 'yes' or 'rather yes' to this question, while men and women who chose to state 'no' or 'rather no' consisted of $2.71 \%$ of all female respondents and $2.13 \%$ of all male respondents. Some $2.70 \%$ females and $2.13 \%$ of all males stated "I don't know" (Figure 5).

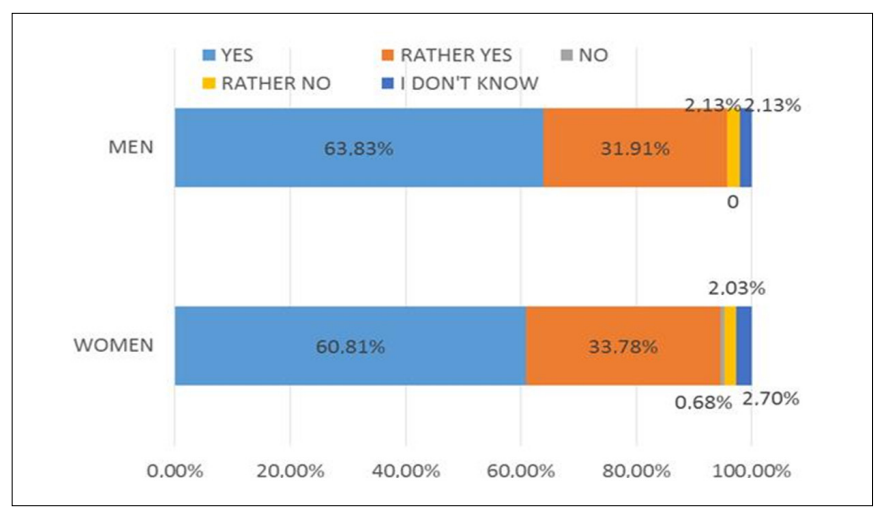

FIGURE 5. Do you have good relationships with your peers? (Pearson's Chi': 0.859896, $\mathrm{df}=4, \mathrm{p}=\mathbf{0 . 9 3 0 2 4 3}$ ).

\section{DISCUSSION}

Based on the results, approx. $45 \%$ of all respondents firmly stated that they were overloaded with work related to their studies. Female respondents were particularly likely to express that opinion (over 50\%). Regarding the combined categories of 'Yes', and 'Rather yes', for all respondents, the obtained figure was $71 \%$, while for that of women alone this figure was $76 \%$. Thus, it can be said that for approx. $3 / 4$ of the students who took part in the research, their study obligations induce stress. This confirms the study of Skrzypek et al., who found that students of medical studies have a lower quality of life with regard to social activity and level of stress [9]. Moreover, the study by Ziemska et al. shows that only $68 \%$ of all respondents thought that they had chosen an appropriate course of study. This shows the level of discouragement that the burden of medical study induces [10]. Furthermore, more than $62 \%$ of all respondents stated that they either had no free time (34\% of all students, $26 \%$ of all male respondents and $39 \%$ of all female respondents) and rather no free time. Lack of time for leisure has negative implications over mental health. Moreover, this lack of free time and degreed of study burden leads to mental and emotional over-load, is evidenced by the fact that over $90 \%$ of the respondents answered affirmatively that the degree of load they encounter in their field of study leads to a high degree of perceived stress $(34 \%$ of all females and $15 \%$ of all males). The striking difference in the choice of answer seemingly implies that female students of medicine have less psychological resistance to the burden of study. In the work of Baran et al., which measured the level of distress imposed by university studies and which was self-perceived as being brought about by demotivating stress, it was noted that women studying medicine experienced a lack of sleep and that they self-assessed as having the highest degree of distress [13]. It needs emphasizing that such expressions were mainly made by women, not men [14].

The results also confirmed the work of other researchers that hold that, world-wide, the level of psychological distress amongst students or the general population is higher for those studying medicine [14]. Indeed, the work of Ziemska et al. reveals that more than $21 \%$ of their respondents sought the aid of psychological and psychiatric practitioners. Furthermore, in doing so, approx. $36 \%$ stated that they had benefitted from such assistance. What is more, almost $22 \%$ of all medical students reported sleep disturbances, $31 \%$ stated that they experienced impaired concentration and attention to some degree, and more than $22 \%$ of all medical students stated that they had other unmanageable problems with the mental sphere [10]. Apart from the above mentioned, however, the study by Marek $\mathrm{K}$. et al., revealed that amongst their subjects (again, medical students), the prevalence of depression was significantly lower at about $6.2 \%$, in comparison to students studying the humanities and teaching $(30.3 \%)$, or sociology $(25 \%)$, or the natural world, agricultural, forestry and fishing (21.9\%) [15]. Of further note, it seems that the workload of medical students did not significantly affect their relationships with their peers, as only $2.5 \%$ of all respondents admitted to a degree of interpersonal hostility. Hence, despite the lack of free time, medical students are able to work together and "get along" with their colleagues. This is comforting news, especially due to the escalating problems with relationships reported in today's world.

\section{CONCLUSIONS}

1. Medical students tend to be overburdened with responsibilities.

2. Therefore, they do not have enough leisure time for themselves.

3. For some of them, this situation induces stress, but overall this situation does not significantly affect their relationships with their peers. 


\section{REFERENCES}

1. Behere SP, Yadav R, Behere PB. A Comparative study of stress among students of medicine, engineering, and nursing. Indian J Psychol Med. 2011;33(2):145-8.

2. Dutta AP, Pyles MA, Miederhoff PA. Stress in health professions students: myth or reality? A review of the existing literature. J Natl Black Nurses Assoc. 2005;16(1):63-8.

3. Mojs E, Warchoł-Biedermann K, Głowacka MD, et al. Are students prone to depression and suicidal thoughts? Assessment of the risk of depression in university students from rural and urban areas. Ann Agric Environ Med. 2012;19(4):770-4.

4. Mojs E, Warchoł-Biedermann K, Głowacka MD, et al. Are students prone to depression and suicidal thoughts? Arch Med Sci. 2015;11(3):605-11.

5. Siamak K, Hashim Intan HM, Mohd-Zaharim N. Perceived stress, positive-negative emotions, personal values and perceived social support in Malaysian undergraduate students. Int J Psychol Behav Sci. 2012;2(1):1-8.

6. Heitzman J. Zagrożenia stanu zdrowia psychicznego Polaków. Nauka. 2010;4:53-9.

7. Woynarowska B. Edukacja zdrowotna. Podręcznik akademicki. Warszawa: PWN; 2010.
8. Marcinkowska U, Lau K, Jośko-Ochojska J. O potrzebie kształcenia studentów medycyny w aspekcie wiedzy o stresie - w ramach zajęć fakultatywnych. Hygeia Public Health. 2013;48(2):152-5.

9. Skrzypek M, Piątkowski W, Brysiewicz A, Wszędyrówny M. Analiza jakości życia studentów w kontekście stylu radzenia sobie ze stresem. Raport z badań. Ann Universitatis Mariae Curie-Skłodowska Lublin. 2001;24(21):261-75.

10. Ziemska B, Marcinkowski JT. Badania nad stresem psychologicznym związanym ze studiami medycznymi. Now Lek. 2008;77(2):120-5.

11. Andrews B, Wilding JM. The relation of depression and anxiety to lifestress and achievement in students. Br J Psychol. 2004;95(4):509-22.

12. Zaid ZA, Chan SC, Ho JJ. Emotional disorders among medical students in a Malaysian private medical school. Singapore Med J. 2007;48(10):895-9.

13. Baran S, Teul I, Lorkowski J. Poziom dystresu jako wskaźnik zdrowia psychicznego młodzieży akademickiej. Ann Acad Med Stetin. Roczniki Pomorskiej Akademii Medycznej w Szczecinie 2012;58(2):17-21.

14. Dyrbye LN, Thomas MR, Shanafelt TD. Systematic review of depression, anxiety, and other indicators of psychological distress among U.S. and Canadian medical students. Acad Med. 2006;81(4):354-73.

15. Marek K, Białoń P, Wichowicz H, et al. Przesiewowa ocena rozpowszechnienia objawów depresyjnych i lękowych wśród studentów Akademii Medycznej w Gdańsku. Psychiatr. 2005;2(4):217-24.

\section{Corresponding author}

Marta Lis-Sochocka

Chair and Department of Histology and Embryology with Experimental Cytology Unit, Medical University of Lublin,

11 Radziwiłłowska Str, 20-080 Lublin

tel. 814486153

E-mail: martasochocka@wp.pl 